\title{
寒中コンクリート断熱養生温度履歴の予測計算 \\ THE METHOD OF CALCULATING CONCRETE TEMPERATURE BY INSULATION FOR CURING IN WINTER CONCRETING
}

\author{
長島 弘* \\ Hiroshi NAGASHIMA
}

\begin{abstract}
The purpose of our study is finding the curing method to keep the concrete which was placed in constructin work of winter warm without warming up the concrete with the heat. I measured concrete rising adiabatic temperature of four kinds of cements with several different concrete placing temperature. Through this experiment, I determined the system of calcurating the experimental constants of the accumulative calorie of hydration from time-temperature functions.

I also made the graph which made the plan easy to do in winter construction work.
\end{abstract}

Keyword : Winter concreting, Insulation for curing of new Concrete in Winter, Hydration of cement, The method calculating of the concrete temperature after placing

寒中コンクリート工事、寒中コンクリートの保温養生、セメントの水和熱、打込み後のコンクリート温度の計算法

\section{1.はじめに（今までの経過を含む）}

この研究は、寒中コンクリート工事の断熱養生計画で、部材コン クリートの発熱条件と放熱条件に応じて部材の温度履歴を予測し、 初期養生を合理的に計画するためのものである。

マスコンクリートでは打込後の温度履歴を予測する方法として、 多種類の単位セメント量と多種類の打込み温度のコンクリートの断 熱温度上昇実験が行われ、セメントの種類、打ち込み温度別に実験 式とその実験定数が整理されている。その式で打込み条件に応じた 部材中心部の温度履歴を求めて、部材内部の熱伝導と表面の放熱条 件から、泠却中の温度履歴を計算する方法が用いられている。しか し建築の寒中コンクリート工事のように部材が薄く、気温が低いた めに泠却が早い場合、セメント水和熱の発生はかなり遅れる。その ため部材中心部の温度は、断熱温度上昇している温度履歷の計算値 と、奏状との差が大きくなり、その計算誤差は危険側になる。 セメント水和熱発生履歷を時間温度関数を用いて予測する計算方 法として、Rastrup ${ }^{1)}$ は温度が $10^{\circ} \mathrm{C}$ 高くなると反応速度は 2 倍にな ることから、時間温度関数Rの式(1) を提案した。

$$
\mathrm{R}=\sum_{0}^{\mathrm{n}} 2^{0.1 \cdot \mathrm{Th}_{\mathbf{n}}} \cdot \Delta h
$$$$
\text { ここに }
$$

\section{$\mathrm{R}$ : 主として中期以降の水和熱進行度を示す時間温度関数 \\ $\mathrm{h}$ : セメントの水和開始からの時間 (hour)}

$\Delta \mathrm{h}:$ 微小時間 (hour)

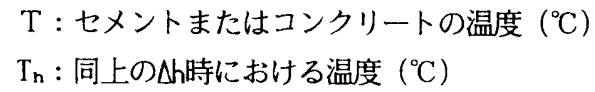

\section{[今までの研究経過]}

今回のコンクリートの断熱温度上昇実験で、混和剤を用いない普 通ポルトランドセメントの単位セメント量 $300 \mathrm{~kg} / \mathrm{m}^{3}$ のコンクリート で、打込み温度が $3.7,10,15,23^{\circ} \mathrm{C}$ のメントの水和熱発生量と時間 温度関数 Rの関係を図 1 の右に示したが、打込み初期に打込み温度 の影響が大きい。前回の研究 ${ }^{2)}$ では、セメントの水和熱進行度をユ ンタクションカロリーメーターで測定した。その実験結果の解析か ら、時間温度関数 Rが初期に温度影響を受ける欠点を補う目的で、

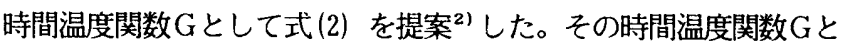

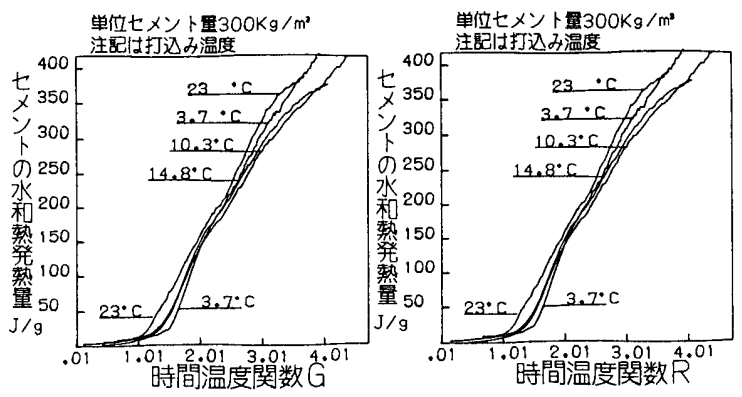

図 1 時間温度関数 G、Rとセメント水和熱発熱量の例 
前記 Rと同条件の水和熱発生量との関係例を図 1 の左に示した。

$$
\begin{aligned}
& G=\sum_{0}^{h}\{\log (h+\Delta h)-\log (h)\} /\left(115-T_{n}\right) \\
& \text { ここに }
\end{aligned}
$$

$G:$ 初期の水和発熱を分担する時間温度関数

そしてセメントの発熱過程を予測する計算では、GとRの二種類 の時間温度関数により、セメントの水和熱発生程度を表現すること を提案した。また、二種類の時間温度関数（GとRの各累積値）と セメントの累積発熱量との関係は、正規分布累積曲線によると仮定 し、セメントの発熱量の予測計算方法として式(4) を提案したもの である。式(4) は第一項にセメントの融解熱があり、引き続き二種 類の時間温度関数の $\mathrm{G}$ (第二項) と、 $\mathrm{R}$ (第三項) の增加に応じて 水和熱の発生量が増加するように発熱を分担させたものである。 第一項：最初にセメントと水が接触した直後に融解熱 $\mathrm{Q}_{1}$ の $16.7 \mathrm{~J} / \mathrm{g}$ $(4 \mathrm{cal} / \mathrm{g})$ が発生する。2 時間以降には融解熱は発生しない。 第二項 : 次に初期（ドルマント期）は時間温度関数Gの進行に伴い $Q_{2}$ の)およ $83.7 \mathrm{~J} / \mathrm{g}(20 \mathrm{cal} / \mathrm{g})$ が急速に発熱する。

第三項 : そして、時間温度関数 $\mathrm{R}$ の進行に伴い $Q_{3}$ の251.2 334.9 $\mathrm{J} / \mathrm{g} \quad(60 \sim 80 \mathrm{cal} / \mathrm{g})$ か、、発熱中期に多く発熱する。

そして発熱量 $\mathrm{Q}_{2}$ と $\mathrm{Q}_{3}$ は, 時間温度関数 $\mathrm{G}$ と Rの累積値で評価さ㧈 る進行度に応じて、正規分布型で整理した。そして実験結果に適合 する実験定数を定めたものである。

$$
\begin{aligned}
Q_{E}= & Q_{1}+Q_{2}+Q_{3} \\
Q_{n}=Q_{1} & +Q_{2} \cdot \sum_{0}^{n}\left(\frac{1}{\sqrt{2 \cdot \pi \sigma_{G}}}\right) \frac{-\left(\bar{G}-\bar{G}_{3}\right)^{2}}{-\cdot \sigma_{G}} \\
& +Q_{3} \cdot \sum_{0}^{n}\left(\frac{1}{\sqrt{2 \cdot \pi \sigma_{R}}}\right) \frac{-\left(\log _{10} \bar{R}-\log _{10} R\right)^{2}}{2 \cdot \log \sigma_{R}}
\end{aligned}
$$

ここに

$Q_{E}:$ セメントの実験最終水和熱発生量 $(\mathrm{J} / \mathrm{g})$

$Q_{1}, Q_{2}, Q_{3}$ : セメントの発熱過程で各期の全水和熱量 $(\mathrm{J} / \mathrm{g})$

$\mathrm{Q}_{\mathrm{n}}$ :セメントの水和開始から $\mathrm{h}$ 時間経過までの累積水和熱発 生量 $(\mathrm{J} / \mathrm{g})$

$\bar{G}:$ 時間温度関数 $\mathrm{G} \sigma$ 分布の平均值

$\sigma_{\mathrm{G}}:$ 同上の正規確率分布の標準偏差

$\overline{\mathrm{R}}:$ 時間温度関数 $\mathrm{R}$ の分布の平均値

$\sigma_{\mathrm{R}}:$ 同上の正規確率分布の標準偏差

前報告では、普通ポルトランドセメントで、混和剤を用いないコ ンクリートのみについて考察を進めた。

以上が前報告までの研究経過の概要であるが、時間温度関数の式 (1) (2)では、当時強度増進との関連づけを考慮して $-10^{\circ} \mathrm{C}$ を基準と したが、強度との相関は少ないことが分かり、今回 $0{ }^{\circ} \mathrm{C}$ 基淮に改 めた。しかし水和熱発生量を計算する式(4) は変更していない。

今回は普通ポルトランドセメント以外のセメントの種類について また备種の混和剤を用いた場合について、コンクリートの断熱温度 上舁実験を行った。その実験結果から実験定数を求めて、セメント の水和熱発生量の計算法として整理し、断熱養生計画用図表として 提案するものである。

また図 2 は、断熱温度上昇実験の実測温度履歴と、「温度応力解 析」ソフト (日本コンクリート工学協会) が採用している塚山の断
熱温度上昇曲線の温度履歴と、本研究による 2 種類の時間温度関数 を用いた温度履歷計算値とを比較した例である。本研究の計算方法 の方が、初期の温度履歷実測值に近似している。

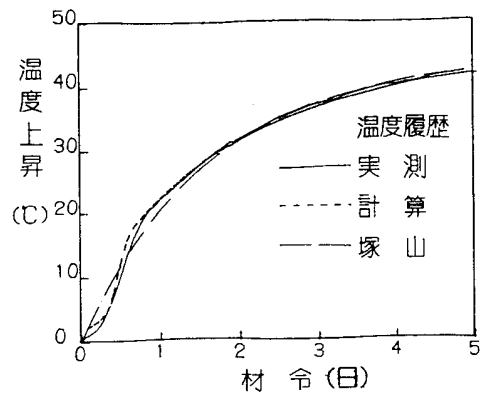

図2＼cjkstart断熱温度上昇実測温度履歴と子測温度履歴の例

\section{2. コンクリートの断熱温度上昇実験}

\section{1 コンクリートの材料}

(1) セメント

$$
\begin{aligned}
& \mathrm{a} \text { : 普通ポルトランドセメント (普通セメントと略す) } \\
& \mathrm{b} \text { : 早強ポルトランドセメント (早強セメントと略す) } \\
& \mathrm{c} \text { : 高炉セメントB種 (高炉セメントと略す) } \\
& \mathrm{d} \text { ：フライアシュセメントB種 (フライアシュと略す) }
\end{aligned}
$$

（注）いづれも日本セメント（株）上磯工場製

(2) 骨材

粗骨材：幕別町依田産 $25 \mathrm{~mm}$ 比重2.66 細骨材：幕別町依田産 $2.5 \mathrm{~mm}$ 比重2.62

(3) 混和剂

混和剤は、北海道内て販売されている主要銘柄を選択した。 妵英小文字の後ろの数字はメーカー番号

A E剤

a 2 : 天然樹脂塩

A E減水剂

b 1 : リグニンスルフォン酸塩

b 2 : オキシカルボン酸塩

b 3 : ビドロキシ系複合体天然樹脂塩

b 4 : リグニンスルフォン酸塩十ポリオール複合体

高性能A E減水剤

C 1：ポリカルボン酸

c $2:$ アニオン型

c 3 : アミノスルフォン酸系

流動化剤

d 1 : 変性メチロールメラミン縮合物

d $2:$ 特殊高分子系

d 3 : ポリアルキルスルフォン酸塩

d 4 : メラミンスルフォン酸

A E 減水剂· (促進型)

e 1 : リグニンスルフォン酸ロダン化合物

e 3 : オキシカルボン酸含公素系化合物

耐寒剂

f 1 : ポリグリコールエステル 


\section{f 2 : 窒素系化合物}

f $3:$ 窒素系化合物+ヒドロキシン

\section{2 断熱温度上昇実験装置}

コンクリートの断熱温度上昇の実験装置は、図3のようにコンク リートを魔法ビン（柴田科学器械工業試)・試容積9.5 le)に入 れ、容器内のコンクリート試料中心温度と、その周囲の水温が常に 同じ温度を保つ温度追随制御装置で、ヒーターおよび冷凍機により 水温を管理する（田尻機械工業制製）。この一連の実験を始める前 に、この装置と試料 30 ｌの断熱温度上昇実験装置（空調型）と、 同じコンクリート試料で比較実験を行い、ほとんどの時刻で温度が 一致（最大で0.2 ${ }^{\circ} \mathrm{C}$ 䛊差）することを確認した。また魔法ビン中 のコンクリート温度および水槽の水温は、銅コンスタンタン線でア ナログ\&デジタル印字記録計（千野AH520-RNN）と慗ぎ、温度を一時 間間隔で記録した。しかし水槽がプラスチック製であることと、冷 却能力がやや劣ることから、温度が約 $90^{\circ} \mathrm{C}$ 以上の実験結果に多少疑 問が残るために、80 $80^{\circ} \mathrm{C}$ 人のDATAは、実験定数の選定DATA、および 計算䛊差の計算から除外した。

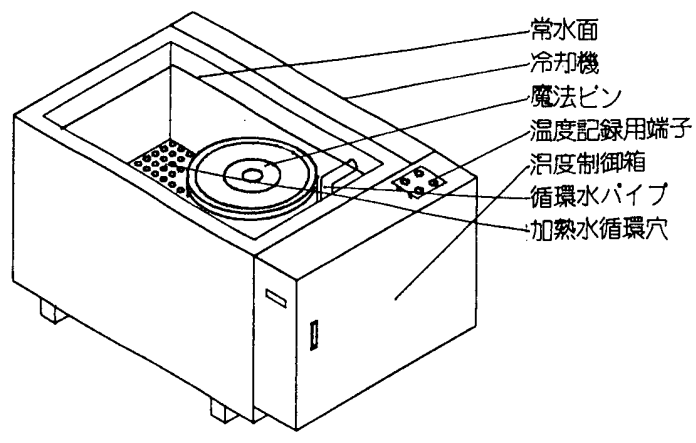

図3 断熱温度上昇実験装置

\section{3. 実験計画および実験結果}

コンクリートは単位セメント量は $300 \mathrm{~kg} / \mathrm{m}^{3}$ 、打込み目標温度 $15^{\circ} \mathrm{C}$ $\pm 1.5{ }^{\circ} \mathrm{C} 、$ スランプ $15 \mathrm{~cm} \pm 2.5 \mathrm{~cm}$ を「基準条件」とし、各シリーズ の目的で変更する条件以外の項目は基準条件によった。

コンクリートの断熱温度上昇実験は、材齢 10 日まで温度測定を 行った。

（1）単位セメント量・打込み温度シリーズ

4 種類のセメントについて、単位セメント量 $200 、 300 、 400 \mathrm{~kg} / \mathrm{m}^{3}$ (普通セメントだけ $250,350 \mathrm{~kg} / \mathrm{m}^{3}$ を含む) について、打込み温度 $23 \pm 1.5{ }^{\circ} \mathrm{C} 、 15 \pm 1.5{ }^{\circ} \mathrm{C} 、 5 \pm 2.5{ }^{\circ} \mathrm{C} 、$ スランプ $15 \pm 2.5 \mathrm{~cm}$ のコン クリートで実験を行った。その実験結果を図4に示す。

(2) 混和剤シリース

普通ポルトランドセメントの単位セメント量 $300 \mathrm{~kg} / \mathrm{m}^{3}$ だけについ て、空気量4. $5 \pm 1 \%$ 、打ち込み目標温度 $15 \pm 1.5{ }^{\circ} \mathrm{C}$ のコンクリート で実験した。その実験結果を図5に示す。

\section{4. 実験結果の整理}

\section{1 セメントの水和熱発生量}

コンクリートの断熱温度上昇実験で、1 時間ごとの温度差につい て、式(5) から一時間当たり発熱量を計算した。これをコンクリー
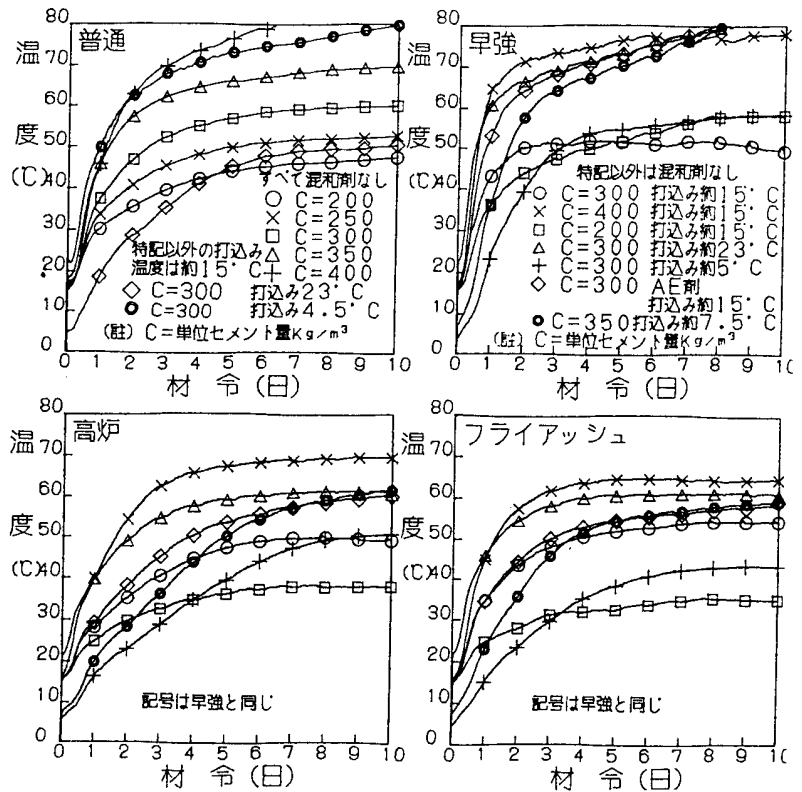

図4単位セメント量・打込み温度シリーズの断熱温度履歴
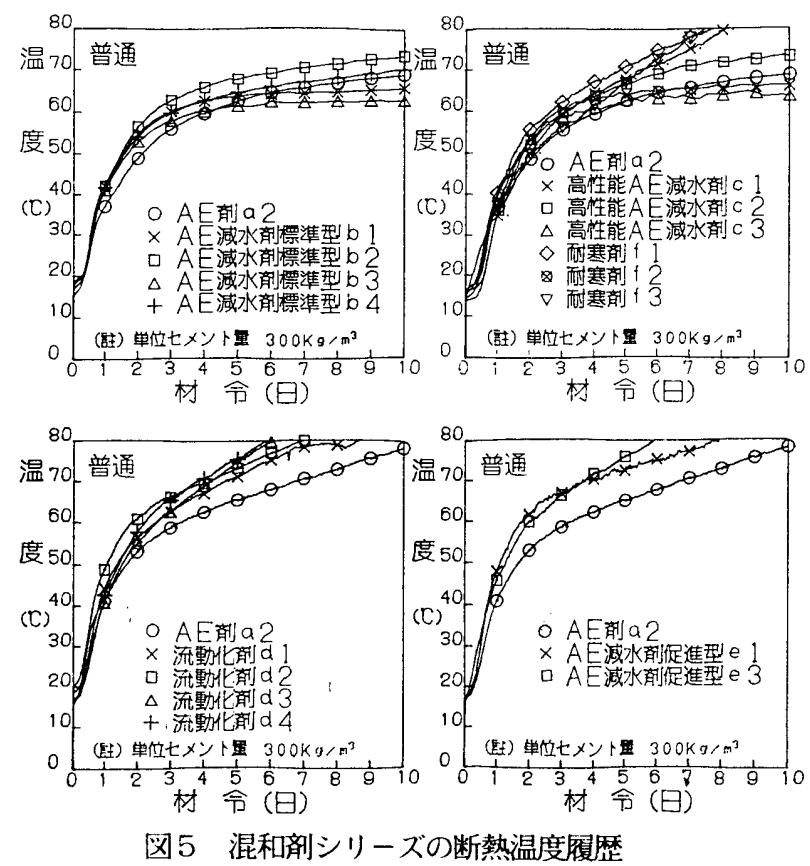

卜打込み直後から累加して水和熱発生履歴とした。

$$
\Delta \mathrm{H}=\Delta \mathrm{T} \cdot 2512 / \mathrm{C} \quad(\mathrm{kJ} / \mathrm{kg} \cdot \mathrm{h})
$$

ここに

$\Delta \mathrm{H}: 1$ 時間当たりセメントの水和熱発生量 $(\mathrm{kJ} / \mathrm{kg} \cdot \mathrm{h})$ $\Delta \mathrm{T}$ : 前時間とのコンクリートの 1 時間当たり温度差 ( $\mathrm{C} / \mathrm{h})$ 2512: コンクリートの容積比熱の仮定值 $\left(\mathrm{kJ} / \mathrm{m}^{3} \mathrm{~K}\right)$

皐コンクリートの容積比熱の仮定値 $600\left(\mathrm{kcal} / \mathrm{m}^{3{ }^{\circ}} \mathrm{C}\right)$ と同じ C : 単位セメント量 $\left(\mathrm{kg} / \mathrm{m}^{3}\right)$

\section{2 第一項の発熱量 $Q_{1}$}

セメントの初期の融解熱Q としていた。今回データーを解析中に、第二項と第三項の熱量のご く少量 $(1.5 \mathrm{cal} / \mathrm{g})$ が、水和開始時に算入されていることが分った。 
それで、各セメント共通にその分を差し引き、各セメント共通に $Q_{1}=10.5 \mathrm{~J} / \mathrm{g}(2.5 \mathrm{cal} / \mathrm{g})$ に変更した。

\section{4、 3 第二項および第三項の実験定数 $\bar{G} 、 \bar{R} 、 \sigma_{G} 、 \sigma_{R} 、 Q_{2}$}

セメントの水和熱発生量は式 (4) によるものとし、コンクリート 温度は、コンクリートの单位セメント量、熱容量から、断熱状態の コンクリート温度を計算するパソコンの「断熱温度履歴計算ソフト 」を作成した。しかし式(4) の第2 項およひ第 3 項で、未知な実験 定数は、 $\bar{G}, \sigma_{\mathrm{G}}, Q_{2}, \overline{\mathrm{R}}, \sigma_{\mathrm{R}}, Q_{3}$ の 6 種類がある。これらの実験定 数を求めるために、過去の経験 ${ }^{2}$ から各変数で予想される範囲内の 仮定值を、前記ソフトに逐次代入して温度履歴を計算し、打込み後 から6,12,24,48,76,120 時間の6材齢について、次の予測誤差を自 動的に計算する「断熱予測誤差計算ソフト」も作成した。

予測誤差 $=($ 断熱温度上昇実験温度 $)-($ 温度履歷計算温度 $)$

各変数の広範囲な仮定值による計算で、6材齢の予測誤差が平均 $\pm 1{ }^{\circ} \mathrm{C}$ 以内で得られた場合に、各変数の仮定值の組み合わせをパソ コンのDISKに記録した。このような検討は、単位セメント量シリー ズ・打込み温度シリーズおよび混和剤シリーズについて、各実験の 実測温度復歴ごとに、それぞれ、次のような五段階で検討し、実験 定数を決定した。

第一段階： 6 種類の各変数の予想される值の範囲内で、それぞ れ大まかな数值間隔の組み合わせについて、パソコンによる断熱温 度履歴の計算を行い、実験值との予測䛊差を求めた。そして子測䛊 差の少ない仮定值の組み合わせを多数選出し、各平均値を求めた。

第二段階： 前記で求めた第二項の予測誤差の少ない変数の仮定 值の平均値を用いて、第3 項の実験定数の仮定値を細かな間隔で仮 定して、それぞれ実験の温度履歴との予測誤差を求めた。そして予 測誤差の少ない第三項の各変数の平均値を求めた。

第三段階： セメントの各種類ごとに前記第三項の各变数のそれ ぞれの平均値を用い、第二項の仮定値を細かな間隔で予測計算を行 い、予測誤差の少ない第二項の $\overline{\mathrm{G}}, \sigma_{\mathrm{G}}, \mathrm{Q}_{2}$ を決定した。

第四段階： 決定した第二項の值を用いて、第三項の $\bar{R}, \sigma_{R}, Q_{3}$ 值を適当な範囲内で細かく仮定し、同様に断熱温度履歷の予測計算 を行った。その予測䛊差が平均 $1{ }^{\circ} \mathrm{C}$ 以内（一部の実験については1. $5{ }^{\circ} \mathrm{C}$ とした）の変数仮定値を多数選出した。

第五段階： 第四段階で選出された多数の実験定数 $\bar{R}, \sigma_{\mathrm{R}}, Q_{3}$ の 値は、各実験シリーズごとに共通な値であることか望ましい。 それで各実験シリーズごとに、予測䛊差が平均士 $1{ }^{\circ} \mathrm{C}$ 以下であった

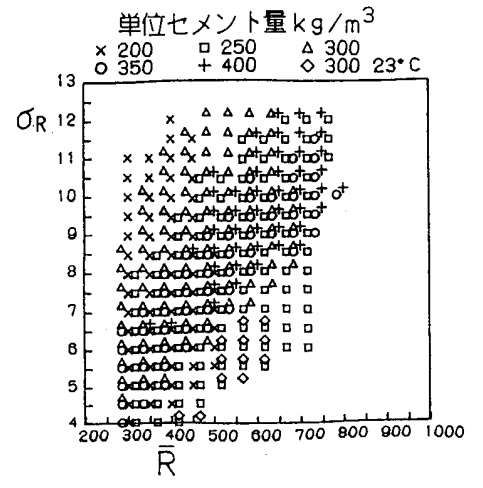

図6 第三項の誤差の少ない変数値をグラフ表示した例
場合の $\bar{R}, \sigma_{\mathrm{R}}$, の値の組合わせについて、一実験ごとに色と形を変 えた記号でパソコンの画面に重複して表示した。普通セメントの単 位セメント量シリーズの例を図6に示す。多くの記号が重複する部 分の值が、各実験で共通に適用できる $\bar{R} ， \sigma_{\mathrm{R}}$, の値であるから、重 複部分の中心付近の值に決定した。その方法で選出したセメントの 各種類の、コンクリートの基準条件の実験定数の值を表1 に示す。

（注）ただし、これらの実験定数の值により式(4) で水和熱発生履 歴を計算した場合には、熱量の単位がcal/g であるため、SI単位の $\mathrm{J} / \mathrm{g}$ に換算する必要がある。このことは表 1、表 3、式(6) 〜式

（13）に共通である。

表 $1 ＼mathrm{~ 式 （ 4 ） に お け る エ 多-ト の 基 準 条 件 の 第 ~} 2$ 項 および第 3 項の実験定数

\begin{tabular}{|c|c|c|c|c|}
\hline セメントの種類 & 普 通 & 早 強 & 高 炬 & フライアッシュ \\
\hline $\begin{array}{c}\bar{G} \\
\sigma_{G} \\
Q_{2}(\mathrm{kcal} / \mathrm{kg})\end{array}$ & $\begin{array}{l}0.0213 \\
0.001 \\
\quad 20\end{array}$ & $\begin{array}{c}0,0198 \\
0.001 \\
21.3\end{array}$ & $\begin{array}{l}0.0200 \\
0.001 \\
12\end{array}$ & $\begin{array}{c}0.0200 \\
0.001 \\
12\end{array}$ \\
\hline $\begin{array}{c}\overline{\mathrm{R}} \\
\sigma_{\mathrm{R}} \\
\mathrm{Q}_{3}(\mathrm{kcal} / \mathrm{kg})\end{array}$ & $\begin{array}{l}550 \\
8.0 \\
76\end{array}$ & $\begin{array}{l}250 \\
6.5 \\
58\end{array}$ & $\begin{array}{l}450 \\
6.0 \\
60\end{array}$ & $\begin{array}{r}450 \\
7.0 \\
78\end{array}$ \\
\hline
\end{tabular}

\section{4 打ち込み温度・単位セメント量と実験定数 $Q_{3}$ の影轓} 前項の第五段階で選出された $\mathrm{R}, \sigma_{\mathrm{R}}$ と同時に仮定されていたQ の值を中心に、多少増減した值を前記ソフトのQ 誤差を計算し、誤差の少ないQ 3 を決定した。その結果単位セメント 量と打込み温度の基準条件を一項目つうつ変更した場合の実験定数は

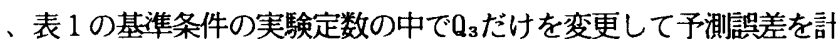
算すると、 $1.5{ }^{\circ} \mathrm{C}$ 以内の誤差で齐むことが分かった。断熱予測誤 差計算ソフトで予測䛊差が少ない $Q_{3}$ の值を求め、単位セメント量お よび打込み温度に対応するQ ${ }_{3}$ の值は図 7 のように得られた。また表 1 のQ ${ }_{3}$ への補正值として求め、式(6) 〜式（13）が得られた。

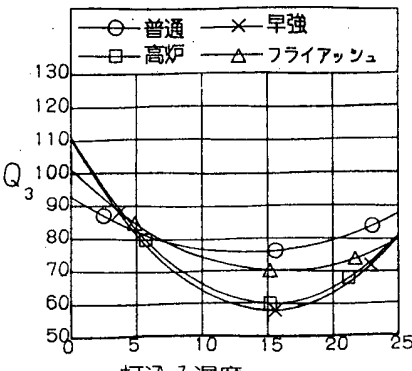

打込み温度 $(\bullet C)$

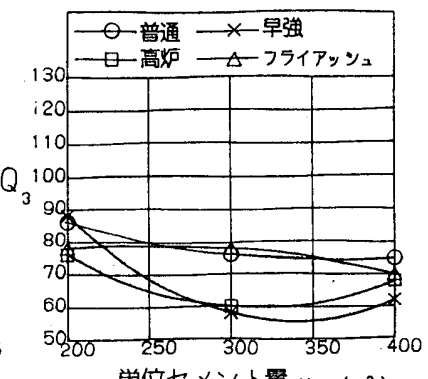

単位七メント嫼 $\left(\mathrm{kg} / \mathrm{m}^{3}\right)$

図 7 打込み温度、単位セメント量と $Q_{3}$ の関係

$Q_{3}$ の単位セメント量および打込み温度による補正

普通セメントの場合

$\Delta Q_{3 \mathrm{~T}}=16.7-2.54 \mathrm{~T}+0.0937 \mathrm{~T}^{2}$

$\Delta Q_{3}=57.0-0.325 \mathrm{C}+0.000445 \mathrm{C}^{2}$

早強セメントの場合

$\Delta Q_{3 \mathrm{~T}}=52.7-6.98 \mathrm{~T}+0.2311 \mathrm{~T}^{2}$

$\Delta Q_{3 \mathrm{c}}=192.0-1.15 \mathrm{C}+0.0017 \mathrm{C}^{2}$

高炉セメントの場合

$\Delta Q_{3 \mathrm{~T}}=51.0-6.74 \mathrm{~T}+0.2218 \mathrm{~T}^{2}$ 
$\Delta \mathrm{Q}_{3 \mathrm{c}}=120.0-0.76 \mathrm{C}+0.0012 \mathrm{C}^{2}$

フライアッシュセメントの場合

$\Delta \mathrm{Q}_{3 \mathrm{~T}}=23.3-3.94 \mathrm{~T}+0.1233 \mathrm{~T}^{2}$

$\Delta Q_{3 \mathrm{C}}=-24.0+0.200 \mathrm{C}-0.00040 \mathrm{C}^{2}$

ここに

$\Delta Q_{3} \mathrm{r} ：$ 打ち込み温度による $\mathrm{Q}_{3}$ の補正量 $\quad(\mathrm{kcal} / \mathrm{kg})$

$\Delta Q_{3 c}$ ：単位セメント量によるQ ${ }_{3}$ の補正量 $(\mathrm{kcal} / \mathrm{kg})$

$\mathrm{T}$ : 打ち込み温度 $\quad\left({ }^{\circ} \mathrm{C}\right)$

C : 単位セメント量 $\left(\mathrm{kg} / \mathrm{m}^{3}\right)$

\section{5 混和剂使用による実験定数の影餢}

(1) AE剂の場合

前述の 2 つ実験シリーズは、プレーンコンクリートを基準とし ているが、単位セメント量・打込み温度の実験シリーズでは、各セ メントの単位セメント量 $300 \mathrm{~kg} / \mathrm{m}^{3}$ の場合だけ、AEコンクリートの 実験も行った。それで、パソコンの断熱温度履歷計算ソフトを改造 して、 $\bar{G} ， \sigma_{G}, Q_{2} ， \bar{R} お よ ひ ゙ \sigma_{R}$ は表 1 の值を用い、第三項の $Q_{3}$ の值 だけを增減して、実験の温度履歴に適合する $Q_{3}$ の値を求めた。それ で試算した結果、Q 3 の值を少し増加させるだけで、実験との予測䛊 差が土1.5 ${ }^{\circ} \mathrm{C}$ 以内で得られることが分かった。その結果を表 2 に示 す。

表 2 プレーンとA E 骭使用の式(4)の $\mathrm{Q}_{3}$ の比較

\begin{tabular}{|c|c|c|c|c|c|c|c|}
\hline \multirow{2}{*}{$\begin{array}{l}\text { 単位セx } \\
\text { 外量 } \\
\text { kg }\end{array}$} & \multirow{2}{*}{$\begin{array}{l}\text { 打込 } \\
\text { 温度 }\end{array}$} & \multirow{2}{*}{$\begin{array}{l}\text { 混和 } \\
\text { 剤 }\end{array}$} & \multicolumn{4}{|c|}{ セメントの種類 } & \multirow[t]{2}{*}{ 平均 } \\
\hline & & & 普 通 & 早 強 & 高 ${ }_{B}$ 燥 & 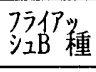 & \\
\hline $\begin{array}{l}300 \\
300\end{array}$ & $\begin{array}{l}15 \\
15\end{array}$ & $\begin{array}{l}\mathrm{AE} \\
\text { ホレーン }\end{array}$ & $\begin{array}{l}85 \\
76\end{array}$ & $\begin{array}{l}84 \\
58\end{array}$ & $\begin{array}{l}85 \\
60\end{array}$ & $\begin{array}{l}80 \\
78\end{array}$ & \\
\hline \multicolumn{2}{|c|}{$\mathrm{Q}_{3}(\mathrm{kcal} / \mathrm{kg})$} & 差 & +9 & +16 & +15 & +2 & +10.5 \\
\hline
\end{tabular}

\section{（2）その他の混和剤の場合}

図5からも考察されるように、混和昘種類ごとに差が生じてい る。同一種類でのメーカー間の差は多少あるが、極端に大きな差は ない。前記同様にパソコンの断熱温度履歷計算ソフトで、Q 変更し他の定数は表 1 のままで試みたが、予測䛊差は小さく出来な かった。それで $\mathrm{R}, Q_{3}$ も変更し、他の定数は表 1 の值のままで、予 測誤差を $1.5{ }^{\circ} \mathrm{C}$ 以下にできた実験定数の值を表 3 に示す。

（3）複数の補正条件で補正を行った予測誤差の例

4 種類のセメントについて、コンクリートの基準条件以外に単位

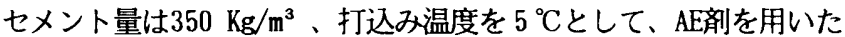
コンクリートの場合について断熱温度上昇実験を行った。その実験 結果の温度履歴と、断熱温度履歷計算ソフトに同実験条件を入力し
て、予測誤差が小さい実験定数蚂を求め、その実験定数を表 4 最下 欄に示した。また表 1 のコンクリートの基準条件のQ $Q_{3}$ との差を、式 (6) 〜式(13)により単位セメント量 $+50 \mathrm{~kg} / \mathrm{m}^{3}$ 、打込み温度 $-7.5^{\circ} \mathrm{C}$ の 補正值 $\Delta \mathrm{Q}_{3 \mathrm{c}}, \Delta \mathrm{Q}_{3 \mathrm{~T}}$ を求め、更にプレーンコンクリートとAEבンク リートの $Q_{3}$ の差を表 2 から求め、それら基準条件の $Q_{3} へ$ へ補正值を 算術計算した計算上補正值 $Q_{3}$ の値を表 4 下から 2 段目に示した。最 下欄 $Q_{3}$ と下から 2 段目の $Q_{3}$ の差は、普通・早強セメントでは特に小 さく、寒中施工では簡易な補正で済むことが分かった。

表 4 複合条件の計算上補正值 $Q_{3}$ と実測値 $Q_{3}$ の比較 单位セメント量 $350 \mathrm{~kg} / \mathrm{m}^{3}$ 、打込み温度 $7.5{ }^{\circ} \mathrm{C}$ の場合

\begin{tabular}{|c|c|c|c|c|c|c|}
\hline \multirow{2}{*}{$\begin{array}{c}\text { 基準 } \\
Q_{3}\end{array}$} & \multirow{2}{*}{ 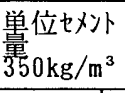 } & \multirow{2}{*}{$\begin{array}{c}\text { 打这み } \\
\text { 温鹿 } \\
1^{\circ} \mathrm{C} \\
\end{array}$} & \multirow{2}{*}{$\frac{\text { 普 通 }}{76}$} & \multirow{2}{*}{$\begin{array}{c}\text { 早 強 } \\
58 \\
\end{array}$} & \multirow{2}{*}{$\frac{\text { 高 炬 }}{60}$} & \multirow{2}{*}{$\frac{\text { フライアッシ }}{78}$} \\
\hline & & & & & & \\
\hline $\begin{array}{l}\text { 補 } \\
\text { 正 } \\
\text { 值 }\end{array}$ & $\begin{array}{l}\text { 式 (8) } \\
\text { 式 (9) } \\
\text { 表 } 2\end{array}$ & $\begin{array}{r}\Delta Q_{3 \mathrm{~T}}= \\
\Delta Q_{3 \mathrm{c}}= \\
\mathrm{AE} \text { 剂補正 }\end{array}$ & $\begin{array}{r}3.8 \\
-2.2 \\
9\end{array}$ & & $\begin{array}{c}14.3 \\
1 \\
15\end{array}$ & $\begin{array}{l}1.8 \\
3.0 \\
2\end{array}$ \\
\hline \multicolumn{3}{|c|}{ 補正計算值合計 $Q_{3}(\mathrm{kcal} / \mathrm{kg})$} & 86.6 & 86.5 & 90.3 & 84.8 \\
\hline \multicolumn{3}{|c|}{ 実測值 $\mathrm{Q}_{3}(\mathrm{kcal} / \mathrm{kg})$} & 85 & 84 & 85 & 80 \\
\hline
\end{tabular}

\section{5. 断熱保温養生施工現場への適用例}

1993年12月～1995年 2 月に北海道大学内の建築工事で、シート（ 一重）上屋の中で、外階段の厚さ $40 \mathrm{~cm}$ 壁のコンクリートが断熱養 生 (無採暖) で施工された。その壁の両面の型枠は、厚12mmの合板 型枠に発泡ウレタンフォーム $50 \mathrm{~mm}$ を吹きつけた保温型染が用いられ た。コンクリートの調合は普通セメントを単位セメント量 $340 \mathrm{~kg} / \mathrm{m}^{3}$ 使用し、各打込み階ごとに耐寒剤のメーカーを変えて施工した実験 的施工現場である。しかし同現場の型枠脱型材齢は、施工会社の都 合で A E 剤a2は 1 日、耐寒剤は 2 日であった（耐寒剂f2の 2 回目だ けは正月休みのために7日）。各施工階ごとにコンクリート部材中 心温度と表面部の温度を、あらかじめ埋設した熱電対で測定した。

打込み後のコンクリート温度の予測計算は、図 2 の断熱温度履歷 計算ソフトに、部材内の熱伝導と部材表面からの放熱を加えて「温 度履歷計算ソフト」を作り、またその計算の気温は、同材齗の現場 の上屋内温度を読み込ませて、計算を行った。

型枠の熱損失係数は、日本建留学会・寒中コンクリート施工指針 - 同解説 (1998)の の104イ-ジの解説表9.3 の「養生上屋内一断熱材 $50 \mathrm{~mm}$ +シート」から、 $\mathrm{K}=1.5 \mathrm{~W} / \mathrm{m}^{2}{ }^{\circ} \mathrm{C}$ と仮定した。また、参考までに多少 增減した $\mathrm{K} の$ 值で計算し、実測積算温度と計算積算温度との詔差を 比較したが、前記の $\mathrm{K}=1.5 \mathrm{~W} / \mathrm{m}^{2}{ }^{\circ} \mathrm{C}$ 場合が、各打込み階の多くの 材齢での哭差が少なかった。

各施工階ごとに、部材中心部と部材表面の実測温度履歴と計算の 温度履歴の比較を図8に示した。また、表 5 には部材中心部と表面

表 3 各種混和㓮の第三項の実験定数（単位セメント量 $300 \mathrm{~kg} / \mathrm{m}^{3}$ で打込み温度 $15^{\circ} \mathrm{C}$ の場合）

\begin{tabular}{|c|c|c|c|c|c|c|c|c|c|c|c|c|c|c|c|c|}
\hline \multirow{2}{*}{\multicolumn{2}{|c|}{$\begin{array}{l}\text { 混和剤種類 } \\
\text { 実験定数 }\end{array}$}} & \multicolumn{3}{|c|}{ A E減水剂 } & \multicolumn{3}{|c|}{ 高性能AE減水剂 } & \multicolumn{3}{|c|}{ 流 動 化 剂 } & \multicolumn{3}{|c|}{ AE減水剂促進型 } & \multicolumn{3}{|c|}{ 耐 寒 剤 } \\
\hline & & $\overline{\mathrm{R}}$ & $\sigma_{R}$ & $Q_{3}$ & $\overline{\mathrm{R}}$ & $\sigma_{R}$ & $\mathrm{Q}_{3}$ & $\bar{R}$ & $\sigma_{R}$ & $Q_{3}$ & $\bar{R}$ & $\sigma_{R}$ & $Q_{3}$ & $\overline{\mathrm{R}}$ & $\sigma_{R}$ & $\mathrm{Q}_{3}$ \\
\hline 銘柄 & $\begin{array}{l}1 \\
2 \\
3 \\
4\end{array}$ & $\begin{array}{l}550 \\
400 \\
550 \\
550\end{array}$ & $\begin{array}{l}8.0 \\
8.0 \\
8.0 \\
8.0\end{array}$ & $\begin{array}{l}82 \\
73 \\
93 \\
80\end{array}$ & $\begin{array}{l}400 \\
550 \\
350\end{array}$ & $\begin{array}{l}8.0 \\
8.0 \\
8.0\end{array}$ & $\begin{array}{l}84 \\
90 \\
80\end{array}$ & $\begin{array}{l}450 \\
550 \\
550 \\
550\end{array}$ & $\begin{array}{l}8.0 \\
8.0 \\
8.0 \\
8.0\end{array}$ & $\begin{array}{l}98 \\
95 \\
93 \\
88\end{array}$ & 500 & 8.0 & 100 & $\begin{array}{l}550 \\
550 \\
550\end{array}$ & $\begin{array}{l}8.0 \\
8.0 \\
8.0\end{array}$ & $\begin{array}{r}100 \\
100 \\
90\end{array}$ \\
\hline \multicolumn{2}{|c|}{ 平 均 } & 512 & 8.0 & 82 & 433 & 8.0 & 85 & 525 & 8.0 & 94 & 525 & 8.0 & 99 & 550 & 8.0 & 97 \\
\hline
\end{tabular}



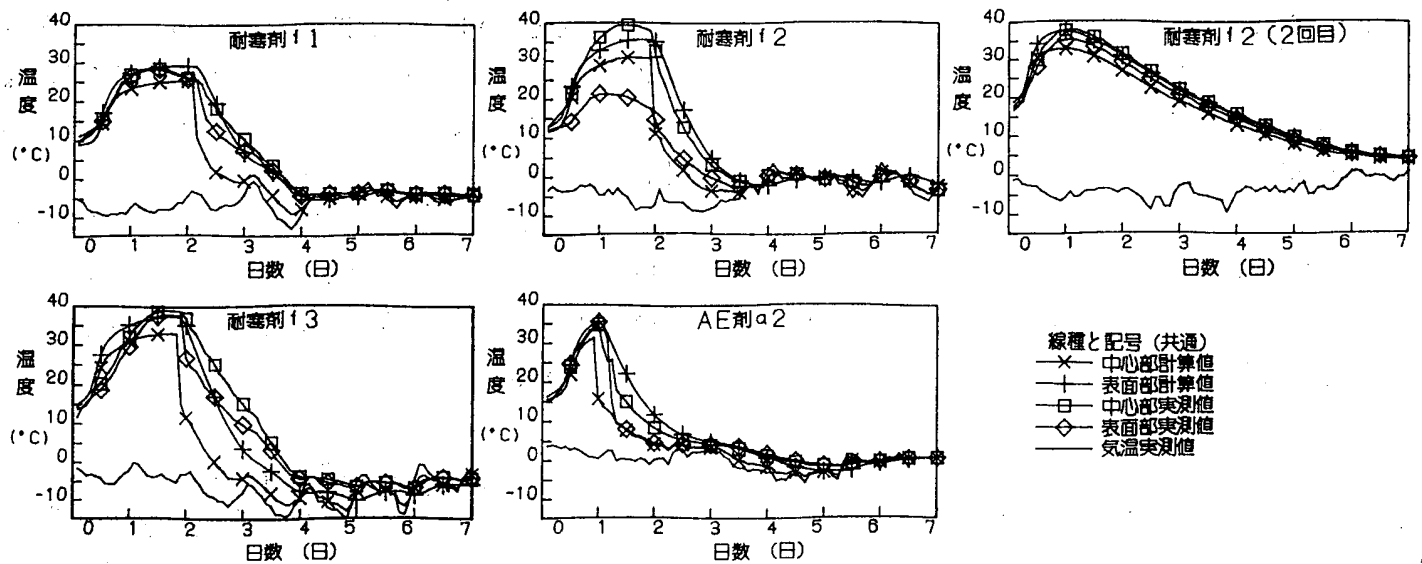

図8 断熱養生の施工現場での実測温度履歴と計算温度履歴の比較

について、各階の奇数材齢ごとに実測温度履歴の積算温度と、計算 温度履歴による積算温度とを示し、また、両積算温度の誤差の比も 示した。その中には誤差が大きい部分もあるが、発熱ピーク直後だ けのため、積算温度の誤差としては最大 $16 \%$ （f2の表面部のセンサ 一取り付け位置不良の疑いを除いて）で済んでいる。

\begin{tabular}{|c|c|c|c|c|c|c|c|}
\hline \multirow{3}{*}{$\begin{array}{l}\text { 鼬 } \\
\text { 剂 } \\
\end{array}$} & \multirow{3}{*}{$\begin{array}{l}\text { 㷊馝 } \\
\end{array}$} & \multirow{2}{*}{\multicolumn{2}{|c|}{ 実測 }} & \multirow{2}{*}{\multicolumn{2}{|c|}{ 計算 }} & \multirow{2}{*}{\multicolumn{2}{|c|}{ 計算／実測 }} \\
\hline & & & & & & & \\
\hline & & 表面 & 中心 & 表面 & 中心 & 表 面 & 中 心 \\
\hline a2 & $\begin{array}{l}1 \\
3 \\
5 \\
7\end{array}$ & $\begin{array}{r}35 \\
70 \\
92 \\
111\end{array}$ & $\begin{array}{r}36 \\
73 \\
95 \\
114\end{array}$ & $\begin{array}{r}35 \\
79 \\
99 \\
117\end{array}$ & $\begin{array}{r}36 \\
85 \\
106 \\
123\end{array}$ & $\begin{array}{l}1.00 \\
1.13 \\
1.08 \\
1.05\end{array}$ & $\begin{array}{l}1.00 \\
1.16 \\
1.12 \\
1.08\end{array}$ \\
\hline f 3 & $\begin{array}{l}1 \\
3 \\
5 \\
7\end{array}$ & $\begin{array}{r}31 \\
102 \\
118 \\
127 \\
\end{array}$ & $\begin{array}{r}32 \\
114 \\
133 \\
141 \\
\end{array}$ & $\begin{array}{r}36 \\
102 \\
108 \\
113 \\
\end{array}$ & $\begin{array}{r}36 \\
109 \\
117 \\
121 \\
\end{array}$ & $\begin{array}{l}1.16 \\
1.00 \\
0.92 \\
0.89\end{array}$ & $\begin{array}{l}1.13 \\
0.96 \\
0.88 \\
0.86\end{array}$ \\
\hline $\mathrm{f} 1$ & $\begin{array}{l}1 \\
3 \\
5 \\
7\end{array}$ & $\begin{array}{r}28 \\
89 \\
106 \\
117\end{array}$ & $\begin{array}{r}28 \\
94 \\
112 \\
124\end{array}$ & $\begin{array}{r}28 \\
91 \\
105 \\
115\end{array}$ & $\begin{array}{r}29 \\
96 \\
112 \\
122\end{array}$ & $\begin{array}{l}1.00 \\
1.02 \\
0.99 \\
0.98\end{array}$ & $\begin{array}{l}1.04 \\
1.02 \\
1.00 \\
0.98\end{array}$ \\
\hline $\mathrm{f} 2$ & $\begin{array}{l}1 \\
3 \\
5 \\
7\end{array}$ & $\begin{array}{r}26 \\
71 \\
89 \\
106\end{array}$ & $\begin{array}{r}34 \\
105 \\
125 \\
142\end{array}$ & $\begin{array}{r}33 \\
99 \\
117 \\
135\end{array}$ & $\begin{array}{r}33 \\
106 \\
124 \\
142\end{array}$ & $\begin{array}{l}1.27 \\
1.39 \\
1.31 \\
1.27\end{array}$ & $\begin{array}{l}0.97 \\
1.01 \\
0.99 \\
1.00\end{array}$ \\
\hline
\end{tabular}

\section{6. 寒中コンクリートエ事断熱養生計画用図の作成}

\section{1 仮定条件}

寒中コンクリートのコンクリートの打ち込み条件として、次のよ うな計算範囲を設定した。

○仮定したコンクリートの条件

セメントの種類 : 普通、早強、高炉 $\mathrm{B}$ 種、フライアッシュ B 種 コンクリートの単位セメント量 : $300 \mathrm{~kg} / \mathrm{m}^{3}, 350 \mathrm{~kg} / \mathrm{m}^{3}$ の 2 種類 混和剂：A E 剂使用

打込み温度 : $20^{\circ} \mathrm{C}, 10^{\circ} \mathrm{C}, 5{ }^{\circ} \mathrm{C}$ の 3 種類

部材は壁・床（無限平板）とし、その厚さは次の8種類とした。

$15,30,45,60,75,90,105,120$ (いずれもcm)

両面の型枠の熱損失係数の和は次の5種類とした。

$26.1, \quad 17.4, \quad 12.8, \quad 5.8, \quad 2.3\left(\mathrm{~W} / \mathrm{m}^{2} \mathrm{C}\right)$

洋上記は $22.5,15,11,5,2\left(\mathrm{kcal} / \mathrm{m}^{2} \mathrm{~h}{ }^{\circ} \mathrm{C}\right)$ と同じ

仮定した気象条件 : 平均気温 $-10^{\circ} \mathrm{C},-5^{\circ} \mathrm{C}, 0{ }^{\circ} \mathrm{C}$
気温日較差： $10^{\circ} \mathrm{C}$

（注）壁・床の両表面の熱損失係数和は、寒中工事で常識的に予想 される最大值として、寒中】夘一指針1998年104ベ-ジ・解説表9.3 で 上屋内の床板 (風速 $1 \mathrm{~m}$, 合板型枠湿潤 7.5 , 保温材なし17.4で計24.9 $\left.\Rightarrow 26.1 \mathrm{~W} / \mathrm{m}^{2 \circ} \mathrm{C}\right)$ を想定し、26.1 W/ $/ \mathrm{m}^{\circ} \mathrm{C}$ とした。

\section{2 温度履歴計算}

温度履歷の計算は 5 の温度履歷計算ソフトに、打込み温度、平均 気温、および型枠の熱損失係数の各条件の総組合わせを、逐次計算 するソフトを作成して行った。その温度履歴計算結果は、コンクリ 一ト打込み後から部材の表面が $0^{\circ} \mathrm{C}$ に冷えるまでに得られる積算温 度としてDISKに記録した。また、その結果の整理に当たり、部材の 泠却し難さを示す指数として式(14)の時間定数 $\tau$ を用いた。

$$
\tau=698 \cdot \mathrm{V} / \Sigma(\mathrm{K} \cdot \mathrm{S})
$$

ここに

$\tau$ : 部材の時間定数 $(\mathrm{h})$

698: コンクリート $1 \mathrm{~m}^{3}$ の熱容量 $\left(\mathrm{W} / \mathrm{m}^{3} \cdot{ }^{\circ} \mathrm{C}\right)\left(600 \mathrm{kcal} / \mathrm{m}^{3} \cdot{ }^{\circ} \mathrm{C}\right)$

$\mathrm{V}$ : 部材のコンクリート容積 $\left(\mathrm{m}^{3}\right)$

$K$ : 部材表面の熱損失俰数 $\left(\mathrm{W} / \mathrm{m}^{2} \cdot{ }^{\circ} \mathrm{C}\right)$

$S$ : 部材の表面積 $\left(\mathrm{m}^{2}\right)$

（注）部材の時間定数 $\tau$ は、寒中エン林揓工指針1998年105 頁、式

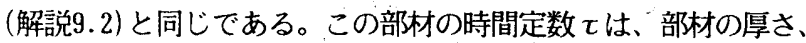
表面の保温程度、風速などによる熱損失の増減などの冷却し難さの 指数として、一元化した眓にすることができた。

\section{3 断熱保温塞生計画用图作成}

前記のコンクリート温度履歴の計算結果から、セメントの種類・ 単位セメント量・打込み温度別に、コンクリートを打込み後部祆表 面が $0{ }^{\circ} \mathrm{C}$ に泠えるまでに得られる積算温度を、外気温別に各マーク で打点して図 9 に示し、各図で平均気温別に積算温度の下限線を設 定した。ただし、下限線よりも10.D-D程度小さい点があるが、その 部材表面が $0{ }^{\circ} \mathrm{C}$ 以下となる時間が 2 時間以内で短いこと、またコン

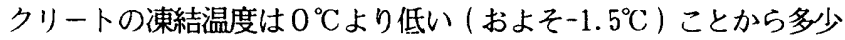
の点は許容して下限線を設定したものである。

(注) フライアッシュ B 種セメントは殆ど使用されていないので、 安全側の高炉セメントの図にまとめた。 


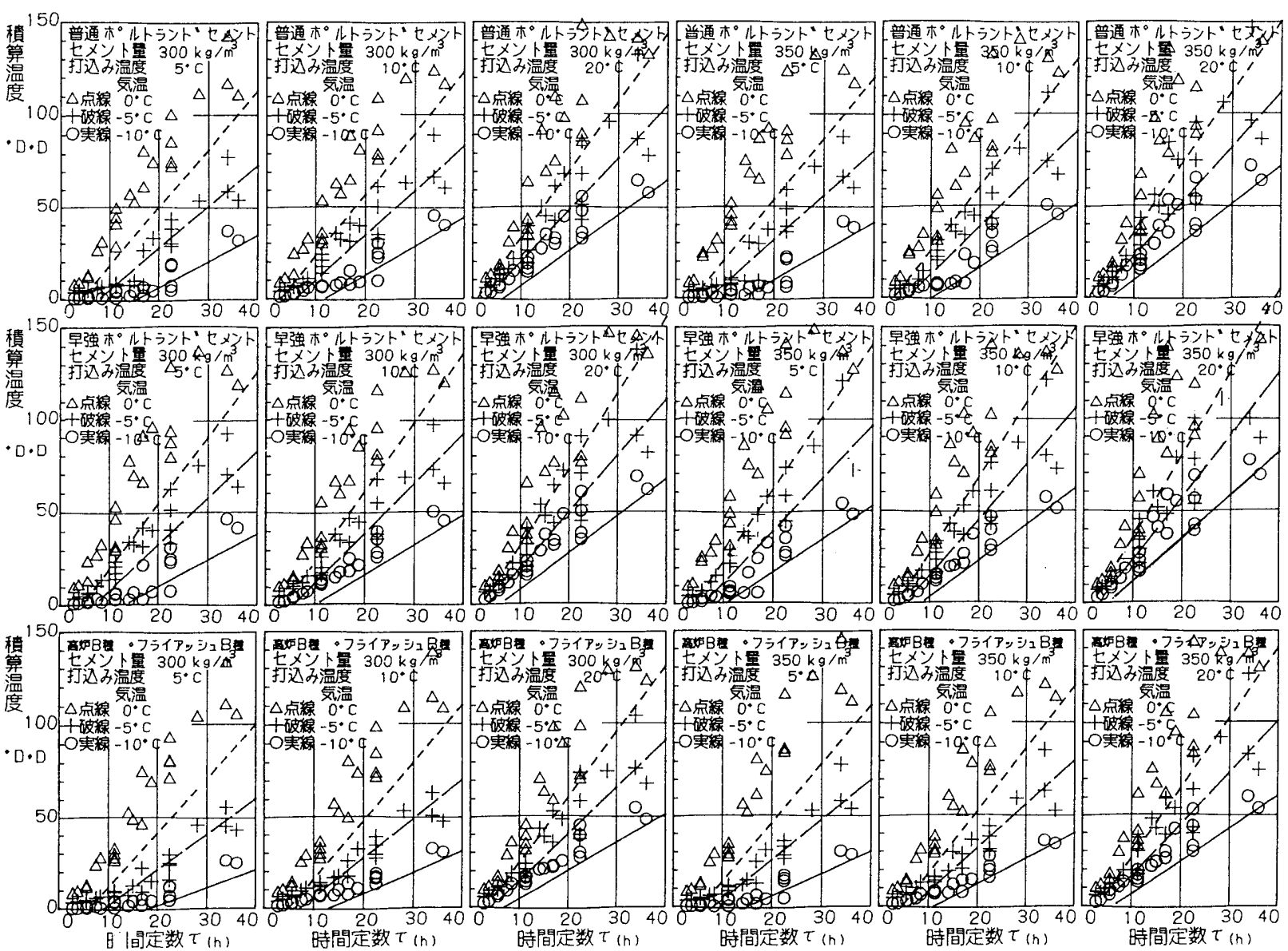

困 9 部材の時間定数とコンクリートが $0{ }^{\circ} \mathrm{C} に$ 泠えるまでに得られる積算温度

\section{4 断熱養生に図 9 が利用できる範囲の考察}

1) 図9の気温別で求める積算温度は28D·D以上とする。

断熱養生で必要な積算温度は、寒中コンクリート施工指針の解説 表9.1 または、解説表 9.2 の最右欄に掲載されている。その積算温 度の最小値は28である。そのため図9の各気温の下限線は、積算温 度が27以下を無視して設定したが、実用上は問題にならない。

2）部材放熱面の熱損失係数の和は $26.1 \mathrm{~W} / \mathrm{m}^{2 \circ} \mathrm{C}$ 以下とする。

図9の作図に当たり計算した熱損失係数の和の範囲は6.2 洋にも 述べたが、 $26.1 \mathrm{~W} / \mathrm{m}^{2} \mathrm{C}$ 以上の値では計算していない。もし更に大き な熱損失係数の和の場合、図9の下限線より小さな值で部材表面が $0{ }^{\circ} \mathrm{C}$ 以下になる恐れがある。また熱損失係数Kの仮定は、寒中コ夘 一指針1998年104 頁・解説表 9.3 を参照されたい。

3) 床で保温材料が非対称に配置されていても使用できる。

コンクリート部材の温度履歴計算ソフトで、部材内部の温度分布 は、差分的解析手法で計算している。それで図 9 では、保温材が非 対称な床の場合には、熱損失係数の大きい部材表面が先に $0^{\circ} \mathrm{C}$ に泠 え、それまでの部材の平均積算温度で作成してある。実際には上屋 内 $($ 風速 $1 \mathrm{~m} / \mathrm{s})$ で床 $(15 \mathrm{~cm})$ を施工する例では、下面が湿潤型枠で上 面が無被覆の場合は、時間定数 $て は 4(\mathrm{~h})$ 程度で、 $0{ }^{\circ} \mathrm{C}$ に泠えるまで の積算温度は少なく、上面も保温しなければ断熱養生はできない。

\section{7.おわりに}

前報から21年経過してしまった。その間にセメントおよび混和剤
の性状も変わったが、今回は断熱養生の実用化の実験を行うことが 出来た。今後寒中の養生計画に役立てていただければ幸いである。

\section{謝辞}

この研究は、小生が北見工大に在職中に、土木開発工学科鮎田耕 一教授の絶大なご好意により実験を行うことができました。また北 見工大卒業生田中聡君、酒井秀一君、片桐礼博君および猪狩平三郎 技官のお世話になりました。また施工例としてフジタ札幌支店佐藤 民佳課長，今野実所長、同温度測定には北大工学部浜幸雄氏のお世 話になりました。ここに、皆様に厚くお礼申し上げます。

\section{参考文献}

1) Erik Rastrup : Heat of Hydration in Concrete Magazine of Concrete Research PP. $79 \sim 92$, Sep. 1954

2) 長島弘：コ夘一打ち込皮後の温度変化に関寸石研究 第 1 報 普通ボルドントセxンの水和熱之時間温度関数 日本建策学会墖文報告集 第 268 号 PP. 1 8，1978、6

3)長島弘：コンク!一打方众双後の温度変化に関寸研究 第 2 報 打込皮後に得られる各材齢の皘算温度 日本建筑学会論文報告集 第 269 号 PP. $31 \sim 38, \quad 1978.7$

4) 長島弘: コンクリート打ち込子後の温度変化に開寸る研究 第3 報 冷却して凍結までに得られる積算温度 日本建築学会論文報告集 第 273 号 $\quad$ PP. 1 12， 1978、11

5) 日本建築学会寒中コンクリート施工指針・同解説 第 4 版 PP. 105, 1998, 2 